\title{
China's Coastal Wetlands: Understanding Environmental Changes and Human Impacts for Management and Conservation
}

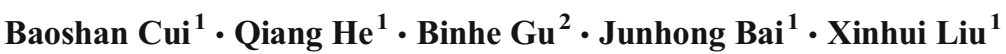

Received: 29 November 2015 / Accepted: 11 January 2016/Published online: 25 January 2016

(C) Society of Wetland Scientists 2016

\begin{abstract}
Anthropogenic activities are substantially changing coastal wetland ecosystems globally. In developing countries such as China, a number of anthropogenic factors associated with rapid population growth and economic development threaten coastal wetlands. In China, notably, coastal wetlands have been increasingly lost to reclamations that are widely adopted to meet the increasing demand for land under rapid economic development. Coastal wetland management requires understanding the patterns of and the mechanisms underlying such human impacts. In this special issue, we synthesize current understanding of environmental changes and human impacts on China' coastal wetlands, focusing on reclamation. Coastal human activities in China are found to change shoreline evolution and wetland hydrology, to deteriorate soil and water quality, to alter vegetation succession, benthic animal and microbial communities, and fisheries, and to impair ecosystem functioning and services. For some of those impacts, new models and indices are developed or applied. We also outline key research areas that should be further studied for effective management of coastal wetlands and successful wetland restoration. We suggest that developing a multi-objective, multi-scenario, and multi-scale framework of integrated management will be crucial to the success of China's coastal wetland conservation with increasing human dominance of the nation's coasts.
\end{abstract}

Baoshan Cui

cuibs@bnu.edu.cn; cuibs67@yahoo.com

1 School of Environment, State Key Laboratory of Water Environmental Simulation, Beijing Normal University, Beijing 100875, China

2 Water Resources Division, South Florida Water Management District, West Palm Beach, FL 33406, USA
Keywords Coastal wetlands $\cdot$ Reclamation $\cdot$ Ecological restoration · Wetland degradation · Estuary · Biodiversity loss $\cdot$ Ecosystem functioning

\section{Introduction}

Anthropogenic activities worldwide are substantially changing coastal wetland ecosystems (Lotze et al. 2006; Halpern et al. 2008). Globally, $35 \%$ of mangroves, $29 \%$ of seagrass beds, and $30 \%$ of coral reefs have been lost over the last few decades (Barbier et al. 2008; Waycott et al. 2009). As coastal wetlands provide many essential ecosystem services for human societies, including storm and hurricane protection, pollution purification, and nursery ground for economically important fisheries (Woodward and Wui 2001; Barbier et al. 2011), sustainable development of coastal societies requires effective measures of wetland conservation and restoration. However, current understanding of the patterns of and the mechanisms underlying human impacts on coastal wetlands is limited, especially in developing regions where humandriven wetland changes are accelerating with rapid population growth and economic development (He et al. 2014). A better understanding of human impacts on coastal wetlands is critical to the success of wetland conservation and restoration.

Anthropogenic factors that threaten coastal wetlands include at least climate change, pollution, and reclamation (Bromberg Gedan et al. 2009). Reclamation, as a way for humans to acquire land and space for industrial development, mariculture, agriculture, urban sprawl, and recreation, is among the most widespread human threats to coastal wetlands. Reclamation has long been adopted in coastal countries worldwide, particularly in Europe and Asia (Bromberg Gedan et al. 2009; He et al. 2014). In The Netherlands, a country that has successfully adopted coastal reclamations for 800 years, 
approximately one-fourth of its territorial land was gained from reclamation (Hoeksema 2007). In Japan, reclaimed areas have grown by $120,000 \mathrm{~km}^{2}$ over the last century, and onethird of the land in coastal cities has been acquired through reclamation (Suzuki et al. 2003). In China, reclamation has also been used for land expansion in coastal regions where population concentrates and there is an increasing shortage of land for economic development (He et al. 2014; Wang et al. 2014). Reclamation has been adopted to develop salt production pans (at early stages of the founding of China), agriculture (in the 1960s and 1970s), and mariculture (in the 1980s and 1990s) (Wang et al. 2014) (Fig. 1). The total area of reclamation grew from $8241 \mathrm{~km}^{2}$ to $13,380 \mathrm{~km}^{2}$ between 1990 and 2008 (Council of Chinese Academy of Sciences 2011). For 2010 to 2020, the State Council of China have approved in total $\sim 2500 \mathrm{~km}^{2}$ of coastal wetlands to be reclaimed, covering all of China's coastal regions (Fig. 2).

With intensifying coastal human activities, human impacts on coastal wetlands have been increasingly studied by wetland scientists, to understand the patterns of and the mechanisms underlying human-driven changes in the structure and functioning of coastal wetlands and to inform effective wetland management and restoration. Reclamations, for example, have been shown in some studies to change the natural patterns of coastal wetlands and block wetland ecological and hydrological connectivity (Richardson and McCarthy 1994; Ferrarin et al. 2015), likely contributing to the outbreak of disasters including floods. Reclamations have also been found to destroy coastal wetland resources, reduce biodiversity (IbarraObando and Poumian-Tapia 1991; de Jong and van der Pluijm 1994; Wu et al. 2005), and affect species interactions in wetland food web networks (Min and Kim 2000). Such activities also affect water quality, reduce water exchange capability, and exacerbate eutrophication and pollution (Anisfeld and Benoit 1997; Portnoy and Giblin 1997; Feng et al. 2004). Moreover, reclamations impair the ecosystem services of wetland ecosystems (Zedler 2003; Wang et al. 2010). While the impacts of human activities on coastal wetlands have been documented in many papers and have been the subject of several reviews (Richardson and McCarthy 1994; Kennish 2001; Lee et al. 2006; Bromberg Gedan et al. 2009), current understanding from developing countries such as China is relatively limited.

This special issue is to provide a synthesis of studies on environmental changes and human impacts on coastal wetlands in China, focusing on reclamations. Here, by summarizing the contents of this special issue, we review the effects of coastal human activities on (1) wetland morphology and hydrology, (2) water and soil pollution, (3) biodiversity and habitats, and (4) ecosystem functioning and services. The implications of those studies for wetland management and restoration are also discussed. To conclude, we highlight major research priorities and challenges that are crucial to furthering understanding of coastal human impacts, wetland management, and restoration of degraded wetlands.

\section{Wetland Morphology and Hydrology}

Coastal human activities, firstly, can modify the morphology of coastal wetlands. In this special issue, Zhu et al. (2016) examine how reclamations affect shoreline morphology between 1987 and 2012 in two regions of the Yangtze River Estuary, China, where reclamations have been intense. Using
Fig. 1 Photographs showing reclamations in coastal China. (a) Coastal wetlands being transformed to artificial ponds in Jiangsu, middle China. (b, c and d) Aerial photographs of reclaimed coastal wetlands for aquaculture in the Yellow River Delta, for urban and industrial development in Shanghai, middle China, and for aquaculture in Zhanjiang, southern China, respectively. Photo credits: Qiang $\mathrm{He}$
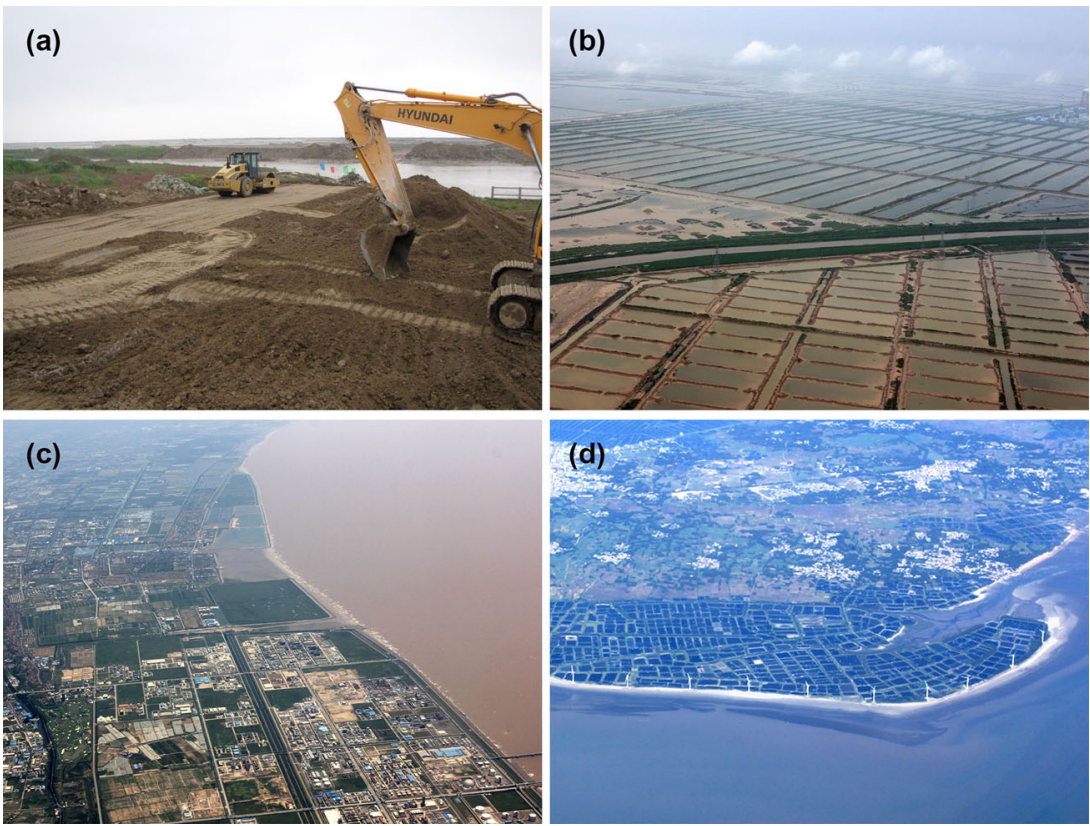
Fig. 2 Coastal provinces/cities in China and coastal reclamation plans for 2011-2020. Data are from Wang et al. (2014)

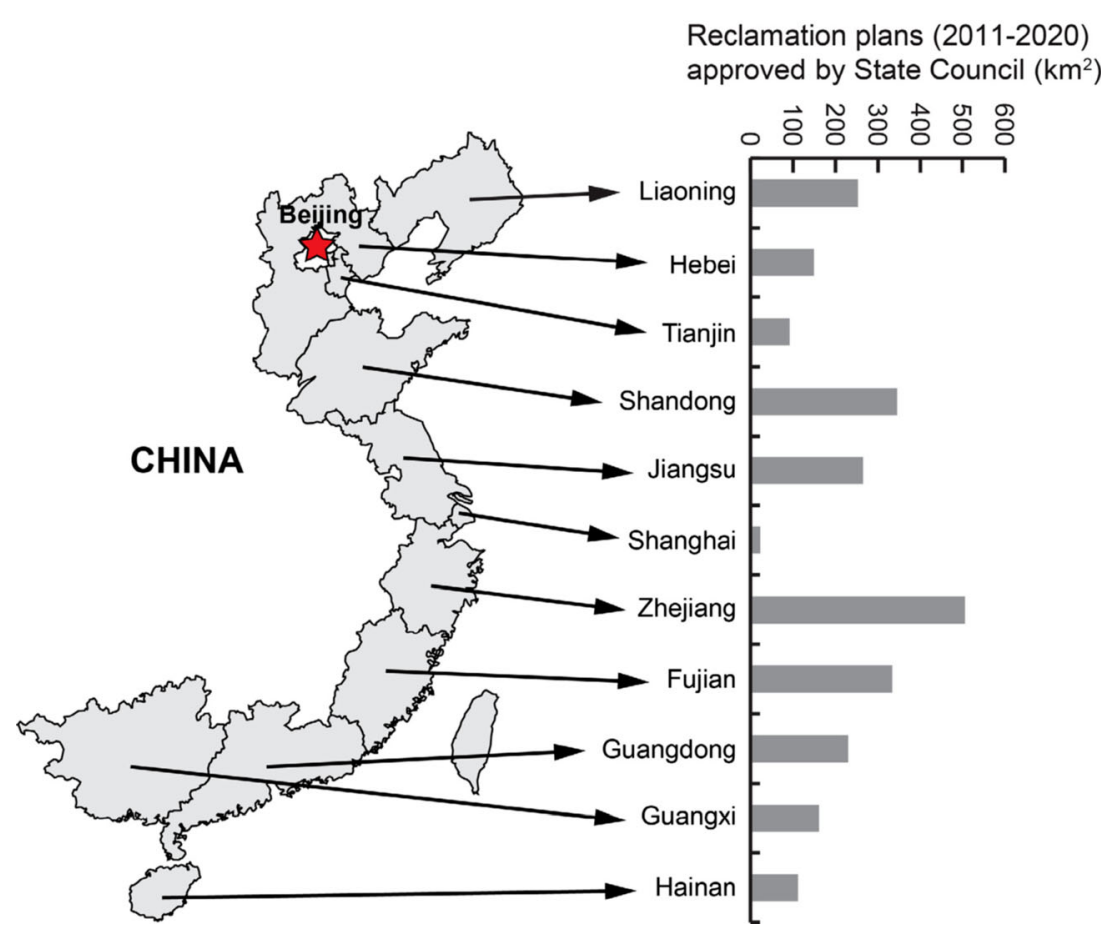

several indices extracted from SPOT satellite images, including length, area change rate, and fractal dimension, the authors show that while shoreline length, wetland area, and fractal dimension generally increased under natural conditions, reclamation activities made it more difficult to predict changes in shoreline morphology a priori. Nevertheless, increased shape entropy, a novel index based on the Shannon formula in information theory, was found to be typically correlated with reclamation intensity, suggesting that shape entropy can be a valuable index for assessing the effects of reclamation activities on shoreline morphology. The authors also demonstrate the value of this index in assessing the impact of reclamation activities in another major estuary in China - the Yellow River Estuary, showing that this index can be applied in other coastal regions or landscapes. Thus, this work provides a new way to assess the impact of land reclamations on shoreline morphology.

A major impact of human activities on wetlands is the direct alteration of the hydrological and hydrodynamic conditions between coastal wetlands and their adjacent systems, such as rivers, oceans, and groundwater. For instance, alterations in hydrological regime and sedimentation caused by reclamation in the Mississippi Delta severely affected coastal wetlands comprising approximately 12,000 mile ${ }^{2}$, which accounted for about $40 \%$ of the salt marshes in the US (Twilley and Rivera-Monroy 2009). Thus, an improved understanding of wetland hydrological processes is important to elucidate the impacts of human activities on coastal wetlands. In this special issue, Liu and Mou (2016) provide a review of interactions between wetland surface water and groundwater.
They suggest that surface water and groundwater interactions play a vital role in controlling water and salinity regimes in coastal wetlands. Human activities (e.g., dam construction, farming) change surface water and groundwater interactions, resulting in altered water and salinity regimes that ultimately affect biological communities in wetlands. Thus, the authors argue that mitigating human impacts on coastal wetlands should be achieved with a better understanding of surface water and groundwater interactions.

\section{Water and Soil Pollution}

Human activities substantially affect environmental water quality, posing threats to human health and regional environmental safety (Hyfield et al. 2008; Mietton et al. 2007). In this special issue, Shao et al. (2016) report seasonal variations in absorption and fluorescence properties of chromophoric dissolved organic matter (CDOM), the light absorbing fraction of dissolved organic matter, in rivers across the Liao River Delta in Northeast China, showing that rivers across the Liao River Delta exhibited strong protein-like fluorescence of CDOM in the water column, indicating serious anthropogenic pollution. Another paper by Cheng et al. (2016) in this special issue examines temporal and spatial trends in ten antibiotics in the water column in the intertidal zone of Bohai Bay, northern China. Their work shows that the total concentrations of those antibiotics ranged from 41.53 to $222.43 \mathrm{ng} \mathrm{L}^{-1}$, levels that were higher than those found in offshore areas. Their work further shows that areas with aquaculture activities or river 
discharge exhibited high concentrations of antibiotics. These studies suggest that intensifying anthropogenic activities are significantly deteriorating water quality in coastal wetlands. Also needed is an understanding of pollutant movement and distribution in wetland flows. Li et al. (2016a) provide an analysis method for predicting the critical length and duration of contaminant cloud in a three-layer wetland flow.

While changes in the water environment are often apparent, soil quality is not unaffected. The same paper by Cheng et al. (2016) shows that the concentration of antibiotics in soil sediments in the intertidal zone of Bohai Bay was high, especially in areas with aquaculture activities. High levels of antibiotics may affect aquatic organisms, change microbial community and function, and promote resistance genes (Huang et al. 2013; Zhang et al. 2013). On the other hand, Yao et al. (2016) examine heavy metal pollution in salt marsh soils in the Yellow River Delta, Shandong, focusing on the impact of oil exploitation. They find that although wetland soils in the Yellow River Delta were not heavily polluted by heavy metals including $\mathrm{Cu}, \mathrm{Ni}, \mathrm{Zn}, \mathrm{Cd}$ and $\mathrm{Pb}$, heavy metal pollution, especially $\mathrm{Cd}$ pollution, was highest in the oil exploitation zone they examined. Furthermore, soil heavy metal concentration was higher in areas without vegetation cover than those with a high cover of vegetation such as Suaeda salsa or Phragmites australis. The authors therefore suggest that coastal wetlands in the Yellow River Delta may become under serious threats of heavy metal pollution with continuing oil exploitation and coastal reclamation. Similarly, Lu et al. (2016a) report their assessment of heavy metal pollution in a shrubby wetland dominated by Tamarix chinensis in the Yellow River Delta. While they also confirm that soil heavy metal contamination was still low in this region, the mean contents of heavy metals including $\mathrm{As}, \mathrm{Ni}, \mathrm{Cr}, \mathrm{Zn}, \mathrm{Pb}, \mathrm{Cd}$ and $\mathrm{Cu}$ all exceeded the background values of the Yellow River Delta, except for $\mathrm{Zn}$ and $\mathrm{Pb}$. Importantly, they find that As pollution contributed most to the total toxic units of heavy metals, and suggest that As pollution should be controlled for the health of ecosystems in this region.

\section{Biodiversity and Habitats}

Although it is relatively well understood that many human activities alter vegetation dynamics in coastal wetlands, the mechanisms underlying such impacts have yet to be better explored. In this special issue, Qi et al. (2016) study how different plant traits and stress types influence vegetation changes after tidal restriction. To do so, Qi et al. propose a relative stress tolerance concept to couple stress tolerance and competitive ability in a dynamic vegetation model. This model was applied to the tidal restriction area of the Yellow River Delta, showing that the key determinants for altered species abundance following tidal restriction for Phragmites australis,
Tamarix chinensis, and Suaeda glauca (should be Suaeda salsa instead) were competitive ability, waterlogging stress, and a combination of waterlogging stress and competitive ability under soil salinity stress, respectively. The authors also find evidence for a hysteretic effect of the hydrological conditions, and that the examined plant community can achieve the same equilibrium state under different extents of tidal restriction. Their model of vegetation response to hydrological changes provides a valuable solution to the difficulty of specifying changing species interactions with changing physical environment in dynamic vegetation models.

Tidal restriction and hydrological changes also affect communities other than plants, such as macrobenthos. Macrobenthos are a key component of biological communities in wetlands. They provide essential wetland functions including decomposition and nutrient cycling, and are food resources for birds and fish (Lee 2008). It is possible that human activities have substantial effects on benthic species. In reclaimed wetlands, for example, soil substrates are often entirely destroyed, thus resulting in catastrophic damages to benthic communities. Except for a few highly mobile benthic species that can escape, most benthic species, including many economically important shellfish, will be buried and die. However, the impact of coastal human activities on wetland macrobenthos has not been studied as well as that on vegetation. In this special issue, $\mathrm{Li}$ et al. (2016b) examine benthic animal responses to tidal restrictions of different stages in the Yellow River Delta, where tidal restriction (and freshwater introduction) has been used to transform salt marshes (viewed as wastelands) into freshwater or brackish wetlands. This study finds that while tidal restriction increased the species richness and density of macrobenthic invertebrates, macrobenthic biomass was highest in areas without tidal restriction. In another paper, Dou et al. (2016) show that hydrological connectivity mediated the diversity and density of macrobenthic invertebrates in the Pearl River Delta, a heavily developed coastal delta in southern China, where macrobenthic diversity and density were greater in high than in low hydrological connectivity riverine habitats. These studies on the responses of macrobenthos to coastal hydrological variation reveal that anthropogenic alterations of coastal hydrology such as those by reclamations can profoundly affect macrobenthic communities in coastal wetlands.

Even less studied are the impacts of human activities on wetland microbial communities. In this special issue, Zhang et al. (2016a) compare the distribution and composition of microbial taxa between reclaimed and non-reclaimed coastal wetlands in the Yellow River Delta. They find that bacterial abundance was significantly lower in reclaimed areas than in non-reclaimed areas and that salinity was the major environmental factor underlying differences in bacterial relative abundance and diversity. Anaerolinea abundance had a 
significantly positive correlation with salinity. As Anaerolinea grows only in anaerobic conditions (Overmann 2008) that are more common in non-reclaimed than in reclaimed areas, the authors suggest that Anaerolinea genus can serve as an indicator of wetland responses to reclamation-associated environment change. Their work provides an interesting perspective of human-driven changes in wetland microbial communities.

Wetland reclamation may also affect coastal fisheries. On one hand, reclamation alters water transparency and dissolved oxygen, which affect fish growth. Fish spawning grounds are often located in shallow-water zones near shores with freshwater inputs, low salinities, and abundant plankton. Reclamation can result in the dispersal of high-concentration suspended particles that damage fish spawns and larvae, severely affecting the habitats and migration of fish (Auld and Schubel 1978; Limburg and Schmidt 1990; Alquezar et al. 2006). This can cause the disappearance of fish spawning grounds, outward movement of fisheries, recession of important fisheries, and declines in fish catch and mariculture. On the other hand, changes in water suspended particles affect the food sources, community structure, and functioning of zooplankton (Bouillon et al. 2000; David et al. 2005). In this special issue, Zhang et al. (2016b) assess the suitability of habitats around the Yellow River Estuary for jellyfish (Rhopilema esculenta) and Chinese shrimp (Penaeus chinensis), two fishery species that are of high economic value and widely distributed in this region (Wang et al. 2006, You et al. 2007). To do so, Zhang et al. employ two habitat indices, namely the Habitat Suitability Index (HSI) and the Habitat Aggregation Index (HAI, which incorporates internal patches and fragmentation of the habitat), based on a fuzzy logic method, and evaluate habitat suitability under different scenarios of terrain conditions to simulate land reclamation activities over the last two decades. Their results show that the suitable habitat areas (assessed based on water depth, temperature, and salinity) for both jellyfish and Chinese shrimp declined substantially over the period of 1989-2009, especially under reclamations between 1999 and 2009. Interestingly, however, habitat quality as indicated by the HAI index showed an increasing trend between 1999 and 2009. The authors suggest that reclamation strongly reduces suitable habitat areas for these fishery species, but the impacts of reclamation may have some positive effects on habitat quality. The methods and indices proposed in this paper are not without limitations, but the fuzzy logic method they employ is potentially valuable for assessing the impacts of reclamations on fisheries habitats, especially for areas that lack field data.

\section{Ecosystem Functioning and Services}

Human activities not only change wetland biological communities, but also quantitatively and qualitatively affect nutrient cycling, energy flow, and other functions of coastal ecosystems. Reclamations, for example, can cause excessive accumulation of nutrients in wetlands, and change the flux of carbon and other materials in deltaic regions and therefore affect the land-ocean-atmosphere carbon exchange (Bianchi and Allison 2009). How human activities affect biogeochemical processes of coastal wetland ecosystems must be systematically investigated. In this special issue, Song and Liu (2016) compare seasonal variations in ecosystem respiration $\left(\mathrm{CO}_{2}\right)$ and $\mathrm{CH}_{4}$ fluxes among seawall blocked wetlands, oil fields, aquaculture ponds, and a Spartina alterniflora-invaded wetland in the Yellow River Delta. The authors find that greenhouse gas emissions were especially high in the Spartina alterniflora-invaded wetland. Blocking wetlands by seawalls may accelerate $\mathrm{CO}_{2}$ emission due to lowered soil moisture, while aquaculture ponds was primarily a source of $\mathrm{CH}_{4}$ and a sink of $\mathrm{CO}_{2}$. Also in this special issue, Shen et al. (2016) analyze the effects of variation in freshwater flow on aquatic metabolism (gross primary production, ecosystem respiration, and net ecosystem metabolism) in the Yellow River Delta, and find that salinity changes driven by the amount of freshwater flow were a primary driver of the metabolism rate of the coastal wetland there. Zhao et al. (2016) examine the spatial and seasonal variations of soil organic carbon (SOC) and total nitrogen (TN) stocks in natural tidal salt marshes in the Yellow River Delta. They find that the relationship between soil organic carbon density (SOCD) and proximity to tide creeks varied with season, and that soil salinity and water content regulated SOC and TN content and stock in the studied salt marshes. In another paper (Lu et al. 2016b) in this special issue, these authors report a field experiment examining how water levels and salinity mediate the total sulfur (TS) content of salt marsh soil in the Yellow River Delta. They find that salinity, rather than water level, primarily mediated the TS content in the top $20 \mathrm{~cm}$ soil at their study site, and that the TS content exhibited high levels of accumulation in the surface soils at all inundation levels. Together, these studies, preliminary in nature, contribute to an understanding of wetland biogeochemistry and how human activities and the resulting alterations in hydrology and salinity may affect the biogeochemistry and functioning of coastal wetlands in China.

Many ecosystem services provided by coastal wetlands, including climate and flood regulation, protection from natural disasters, and pollutant purification can also be impaired by human threats (Zedler 2003; Craft et al. 2009). For instance, reclaiming and draining wetlands, which decreases soil carbon accumulation and storage capabilities, is one of the key factors that drive soil carbon loss in wetlands (Lal 2004). Because of interdependencies between different ecosystem services (Chee 2004; Nicholson et al. 2009), human impact on one ecosystem service can have a ripple effect on other ecosystem services. Scientific assessment of human impacts on the value of wetland ecosystem services has become an essential next 
step towards effective resource use and management of coastal wetland ecosystems (Bianchi and Allison 2009; Perillo et al. 2009). In this special issue, Li et al. (2016c) use emergy analysis to value the inputs, state, and outputs of the ecosystem services following freshwater releases that were to improve the ecosystem functioning of freshwater wetlands in the Yellow River Delta. Their analysis is holistic, including ecosystem services ranging from provisioning (e.g. biomass production), regulating (e.g. $\mathrm{CO}_{2}$ fixation, water purification), cultural (e.g. tourism), to supporting (e.g. maintaining biodiversity) ecosystem services. Their results show that freshwater releases between 2001 and 2008 improved the provisioning, regulating, and cultural ecosystem services from the coastal wetlands. The authors further show that the ability to supply ecosystem services per unit of inputs, indicated by the emergy yield ratio, increased by $71.3 \%$. These results suggest that environmental flows are important to the ecosystem services of the Yellow River Delta wetlands. While this work focused mainly on the hydrological effects on coastal wetland ecosystem services, their methodology should be applicable to analyzing other wetland change issues induced by human activities.

\section{Ecological Management and Restoration}

These studies on human impacts on wetland morphology, hydrology, water and soil pollution, vegetation, benthic animals, microbes, fisheries, ecosystem functioning, and ecosystem services have important implications for management of coastal wetlands and wetland restoration. Indeed, Qi et al. (2016) use their dynamic vegetation model to simulate the response of vegetation to tidal reintroduction, and find that vegetation did not respond during the first four years of tidal reintroduction, due to hysteretic effects, but then recovered rapidly. Thus, the authors recommend rapid alteration of the hydrological regime to reduce hysteretic effects in wetland restorations. Xie et al. (2016) develop a risk-based balance inexact water resources optimization model that considers both wetland ecological water demand and water quality problems for regional water resources management. Li et al. (2016b) show that the current wetland restorations practiced in the Yellow River Delta primarily focused on the reestablishment of freshwater vegetation. Although this project has successfully reestablished dense vegetation and bird populations (Cui et al. 2009), Li et al. reveal that macrobenthos were not always successfully restored. Thus, they recommend evaluating the success of a restoration project with the responses of multiple taxa including vegetation, macrobenthos and waterbirds. What index should be used to assess the success of wetland restoration is indeed highly controversial (Staszak and Armitage 2012). Li et al.'s study contributes to that establishing an integrated index that can comprehensively and accurately reflect patterns and processes of wetlands is an important next step. This study further highlights the importance of adaptive management and long-term monitoring in wetland restorations.

\section{Future Research Priorities}

The studies synthesized in this special issue show that coastal human activities in China, especially large-scale wetland reclamations, not only directly modify wetland morphology and hydrology, but also cause severe water and soil pollution, lead to biodiversity and habitat losses, and impair wetland ecosystem functioning and the ecosystem services they provide, thus having severe and multi-faceted impacts on coastal wetlands. Developing a comprehensive scheme of measures for conservation and management of China's coastal wetlands is thus essential for sustainable development of the coupled humanocean ecosystems in China (He et al. 2014). Here, we propose such a scheme aimed at (1) scientifically managing coastal human activities including reclamations, (2) establishing procedures for restoration of impaired coastal wetlands and ecological compensation, and (3) coordinating socio-economic development and environmental conservation. Achieving these goals would require further studies, especially for the following areas:

\section{(1) Tempo-Spatial Dynamics of Coastal Human Activities} and Wetland Ecological Patterns Future research should reveal the types and distribution patterns of coastal human activities in different geographical regions and socioeconomic development stages in China, to examine differences and similarities between different regions and tempospatial scales, and to quantitatively assess the extent and intensity of coastal human activities (He et al. 2014; Wang et al. 2014). Research also needs to analyze the evolution of ecological patterns and changes in different wetland types, and to reveal tempo-spatial patterns in wetland ecosystem change through comparative analysis of wetlands (Antos et al. 2007). Furthermore, research should identify the relative and combined roles of multiple drivers in wetland ecological pattern change, simulate the feedbacks and changes in wetland ecosystems under different scenarios of human activities and climate change, and quantitatively assess the relative contribution of different types of human impacts to wetland ecosystem change.

(2) Coastal Human Impacts on Wetland Biodiversity and Underlying Mechanisms Future research should quantify the effects of coastal human activities of different intensities on wetland biological communities at different temporal and spatial scales, and reveal the abiotic and biotic processes underlying such effects. For example, research should examine how 
human activities affect hydrological/hydrodynamic conditions and water-salt balance in coastal wetlands, and address the response of wetland sensitive biota to hydrological changes induced by human activities. Also, coastal human activities can cause massive organic pollutants, heavy metals, and nutrients to enter wetland waters. Research should investigate how environmental water quality, such as water environmental issues in mariculture zones, is altered, and explore the linkages of red tide blooms and fishery collapses with human-induced changes in environmental water quality.

(3) Effects of Coastal Human Activities on Wetland Ecosystem Functioning and Sustainable Uses of Wetland Resources Research should examine the effects of different human activities on wetland ecological integrity (structural and functional integrity; De Leo and Levin 1997) and reveal the mechanisms underlying the effects of human activities on wetland functional integrity by studying biological adaptation and ecosystem processes, and by analyzing changes in disturbance resistance, resilience, and stability of wetland ecosystems. Research should develop methods to evaluate wetland ecosystem services and predict changes in wetland ecosystem services under multiple scenarios. Furthermore, research should incorporate potential changes in ecosystem services of various wetland types, as well as variations in controlling factors and uncertainty analysis, to simulate and distinguish the transformation, mutation, and invalidation thresholds of ecosystem services, thereby providing theoretical and technical support for wetland ecological restoration and safety control.

\section{(4) Mechanisms of Restoration of Impaired Wetlands and} Ecological Compensation Research should identify the regions, processes, and patterns that are key to the restoration of wetlands of different types, and explore the methods and procedures in selecting targets for restoration and compensation, determining restoration or substitutional areas, and quantifying the scale of ecological restoration/compensation and the compensation rates for different restoration types. Studies should consider the ecological feasibility and socio-economic boundaries of restorations to simulate and design wetland ecological networks that can be used to regulate regional hydrological processes, conserve biodiversity, enhance the overall functioning of wetland ecosystems, and optimize the resilience and adaptability of wetland networks. Furthermore, research should incorporate social needs and knowledge into wetland ecological networks and connect them effectively to regional social networks, and should incorporate ecological compensation and economic networks into wetland ecological networks. Finally, studies should optimize the structure and functioning of wetland ecological networks under various scenarios, and formulate a multi-objective, multi-scenario, and multi-scale framework for integrated coastal wetland management (Alvarez-Romero et al. 2011).

Clearly, many more studies are needed for a comprehensive understanding of human impacts on China's coastal wetlands and for effective wetland management and conservation. We hope that this special issue can serve as a scientific starting point for a new fruitful line of research and conservation measures, to foster a sustainable future of coastal wetlands and human societies in China, as well as in other developing countries and regions.

Acknowledgments This study was funded by National Key Basic Research Program of China (2013CB430406), China National Funds for Distinguished Young Scientists (51125035), and National Science Foundation for Innovative Research Group (51121003).

\section{References}

Alquezar R, Markich SJ, Booth DJ (2006) Effects of metals on condition and reproductive output of the smooth toadfish in Sydney estuaries, south-eastern Australia. Environmental Pollution 142:116-122

Alvarez-Romero JG, Pressey RL, Ban NC, et al. (2011) Integrated landsea conservation planning: the missing links. Annual Review of Ecology, Evolution, and Systematics 42:381-409

Anisfeld SC, Benoit G (1997) Impacts of flow restrictions on salt marshes: an instance of acidification. Environmental Science \& Technology 31:1650-1657

Antos MJ, Ehmke GC, Tzaros CL, Weston MA (2007) Unauthorised human use of an urban coastal wetland sanctuary: current and future patterns. Landscape and Urban Planning 80:173-183

Auld AH, Schubel JR (1978) Effects of suspended sediment on fish eggs and larvae: a laboratory assessment. Estuarine and Coastal Marine Science 6:153-164

Barbier EB, Hacker SD, Kennedy C, Koch EW, Stier AC, Silliman BR (2011) The value of estuarine and coastal ecosystem services. Ecological Monographs 81:169-193

Barbier EB, Koch EW, Silliman BR, et al. (2008) Coastal ecosystembased management with nonlinear ecological functions and values. Science 319:321-323

Bianchi TS, Allison MA (2009) Large-river delta-front estuaries as natural "recorders" of global environmental change. Proceedings of the National Academy of Sciences 106:8085-8092

Bouillon S, Chandra Mohan P, Sreenivas N, Dehairs F (2000) Sources of suspended organic matter and selective feeding by zooplankton in an estuarine mangrove ecosystem as traced by stable isotopes. Marine Ecology-Progress Series 208:79-92

Bromberg Gedan KB, Silliman BR, Bertness MD (2009) Centuries of human-driven change in salt marsh ecosystems. Annual Review of Marine Science 1:117-141

Chee YE (2004) An ecological perspective on the valuation of ecosystem services. Biological Conservation 120:549-565

Cheng D, Xie Y, Yu Y, Liu X, Zhao S, Cui B, Bai J (2016) Occurrence and partitioning of antibiotics in the water column and bottom sediments from the intertidal zone in the Bohai Bay, China. Wetlands doi:10.1007/s13157-014-0561-y

Council of Chinese Academy of Sciences (2011) Comments on several scientific questions and countermeasures on sea reclamation projects in China. Bulletin of Chinese Academy of Sciences 26:171-173

Craft C, Clough J, Ehman J, Joye S, Park R, Pennings S, Guo H, Machmuller M (2009) Forecasting the effects of accelerated sea- 
level rise on tidal marsh ecosystem services. Frontiers in Ecology and the Environment 7:73-78

Cui BS, Yang QC, Yang ZF, Zhang KJ (2009) Evaluating the ecological performance of wetland restoration in the Yellow River Delta, China. Ecological Engineering 35:1090-1103

David V, Sautour B, Chardy P, Leconte M (2005) Long-term changes of the zooplankton variability in a turbid environment: the Gironde estuary (France). Estuarine, Coastal and Shelf Science 64:171-184

de Jong DJ, van der Pluijm AM (1994) Consequences of a tidal reduction for the salt-marsh vegetation in the Oosterschelde estuary (The Netherlands). Hydrobiologia 282:317-333

De Leo GA, Levin S (1997) The multifaceted aspects of ecosystem integrity. Conservation Ecology 1:3

Dou P, Cui B, Xie T, Dong D, Gu B (2016) Macrobenthos diversity response to hydrological connectivity gradient. Wetlands. doi:10. 1007/s13157-014-0580-8

Feng H, Han X, Zhang W, Yu L (2004) A preliminary study of heavy metal contamination in Yangtze river intertidal zone due to urbanization. Marine Pollution Bulletin 49:910-915

Ferrarin C, Tomasin A, Bajo M, Petrizzo A, Umgiesser G (2015) Tidal changes in a heavily modified coastal wetland. Continental Shelf Research 101:22-33

Halpern BS, Walbridge S, Selkoe KA, et al. (2008) A global map of human impact on marine ecosystems. Science 319:948-952

He Q, Bertness MD, Bruno JF, et al. (2014) Economic development and coastal ecosystem change in China. Scientific Reports 4:5995

Hoeksema RJ (2007) Three stages in the history of land reclamation in The Netherlands. Irrigation and Drainage 56:S113-S126

Huang X, Liu C, Li K, Liu F, Liao D, Liu L, Zhu G, Liao J (2013) Occurrence and distribution of veterinary antibiotics and tetracycline resistance genes in farmland soils around swine feedlots in Fujian province, China. Environmental Science and Pollution Research 20: 9066-9074

Hyfield ECG, Day JW, Cable JE, Justic D (2008) The impacts of reintroducing Mississippi river water on the hydrologic budget and nutrient inputs of a deltaic estuary. Ecological Engineering 32: 347-359

Ibarra-Obando SE, Poumian-Tapia M (1991) The effect of tidal exclusion on salt marsh vegetation in Baja California, México. Wetlands Ecology and Management 3:131-148

Kennish MJ (2001) Coastal salt marsh systems in the U.S.: a review of anthropogenic impacts. Journal of Coastal Research 17:731-748

Lal R (2004) Soil carbon sequestration impacts on global climate change and food security. Science 304:1623-1627

Lee SY (2008) Mangrove macrobenthos: assemblages, services, and linkages. Journal of Sea Research 59:16-29

Lee SY, Dunn RJK, Young RA, et al. (2006) Impact of urbanization on coastal wetland structure and function. Austral Ecology 31:149-163

Li M, Yang W, Sun T (2016c) Effects of freshwater releases on the delivery of ecosystem services in coastal wetlands of the Yellow River Delta using an improved input-state-output approach. Wetlands. doi:10.1007/s13157-015-0630-x

Li S, Cui B, Xie T, Zhang K (2016b) Diversity pattern of macrobenthos associated with different stages of wetland restoration in the Yellow River Delta. Wetlands. doi:10.1007/s13157-015-0641-7

Li Z, Wang P, Sun T, An Y, Wu X (2016a) Critical length of contaminant cloud in a three-layer wetland: multi-scale analysis for environmental dispersivity. Wetlands. doi:10.1007/s13157-015-0663-1

Limburg KE, Schmidt RE (1990) Patterns of fish spawning in Hudson river tributaries: response to an urban gradient? Ecology 71:12381245

Liu Q, Mou X (2016) Interactions between surface water and groundwater: key processes in ecological restoration of degraded coastal wetlands caused by reclamation. Wetlands. doi:10.1007/s13157-0140582-6
Lotze HK, Lenihan HS, Bourque BJ, et al. (2006) Depletion, degradation, and recovery potential of estuaries and coastal seas. Science 312 : 1806-1809

Lu Q, Bai J, Gao Z, Wang J, Zhao Q (2016b) Effects of water level and salinity on total sulfur contents in salt marsh soils of the Yellow River Delta, China. Wetlands. doi:10.1007/s13157-015-0661-3

Lu Q, Bai J, Gao Z, Zhao Q, Wang J (2016a) Spatial and seasonal distribution and risk assessments for metals in a Tamarix chinensis wetland, China. Wetlands. doi:10.1007/s13157-014-0598-y

Mietton M, Dumas D, Hamerlynck O, et al. (2007) Water management in the Senegal river delta: a continuing uncertainty. Hydrology \& Earth System Sciences Discussions 4:4297-4323

Min BM, Kim J-H (2000) Plant succession and interaction between soil and plants after land reclamation on the West Coast of Korea. Journal of Plant Biology 43:41-47

Nicholson E, Mace GM, Armsworth PR, et al. (2009) Priority research areas for ecosystem services in a changing world. Journal of Applied Ecology 46:1139-1144

Overmann J (2008) Green nonsulfur bacteria. eLS, Wiley

Perillo GME, Wolanski E, Cahoon DR, Brinson MM (2009) Coastal wetlands: an integrated ecosystem approach. Elsevier, Amsterdam, The Netherlands

Portnoy JW, Giblin AE (1997) Effects of historic tidal restrictions on salt marsh sediment chemistry. Biogeochemistry 36:275-303

Qi M, Sun T, Zhan M, Xue S (2016) Simulating dynamic vegetation changes in a tidal restriction area with relative stress tolerance curves. Wetlands. doi:10.1007/s13157-015-0639-1

Richardson CJ, McCarthy EJ (1994) Effect of land development and forest management on hydrologic response in southeastern coastal wetlands: a review. Wetlands 14:56-71

Shao T, Song K, Du J, Zhao Y, Ding Z, Guan Y, Liu L, Zhang B (2016) Seasonal variations of CDOM optical properties in rivers across the Liaohe Delta. Wetlands. doi:10.1007/s13157-014-0622-2

Shen X, Sun T, Tang S, Yang W (2016) Short-term response of aquatic metabolism to hydrologic pulsing in the coastal wetlands of Yellow River Delta. Wetlands. doi:10.1007/s13157-015-0710-y

Song H, Liu X (2016) Anthropogenic effects on fluxes of ecosystem respiration and methane in the Yellow River Estuary, China. Wetlands. doi:10.1007/s13157-014-0587-1

Staszak LA, Armitage AR (2012) Evaluating salt marsh restoration success with an index of ecosystem integrity. Journal of Coastal Research 29:410-418

Suzuki T (2003) Economic and geographic backgrounds of land reclamation in Japanese ports. Marine Pollution Bulletin 47:226-229

Twilley RR, Rivera-Monroy V (2009) Sediment and nutrient tradeoffs in restoring Mississippi river delta: restoration vs eutrophication. Journal of Contemporary Water Research \& Education 141:39-44

Wang Q, Zhuang Z, Deng J, Ye Y (2006) Stock enhancement and translocation of the shrimp Penaeus chinensis in China. Fishery Research 80:67-79

Wang W, Liu H, Li Y, Su J (2014) Development and management of land reclamation in China. Ocean \& Coastal Management 102:415-425

Wang X, Chen W, Zhang L, Jin D, Lu C (2010) Estimating the ecosystem service losses from proposed land reclamation projects: a case study in Xiamen. Ecological Economics 69:2549-2556

Waycott M, Duarte CM, Carruthers TJ, et al. (2009) Accelerating loss of seagrasses across the globe threatens coastal ecosystems. Proceedings of the National Academy of Sciences USA 106: 12377-12381

Woodward RT, Wui Y (2001) The economic value of wetland services: a meta-analysis. Ecological Economics 37:257-270

Wu J, Fu C, Lu F, Chen J (2005) Changes in free-living nematode community structure in relation to progressive land reclamation at an intertidal marsh. Applied Soil Ecology 29:47-58

Xie Y, Huang G, Li W, Li Y, Cui J, Sun X (2016) A risk-based balance inexact optimization model for water quality management with 
sustainable wetland system development - a case study of north China. Wetlands. doi:10.1007/s13157-014-0604-4

Yao X, Xiao R, Ma Z, Xie Y, Zhang M, Yu F (2016) Distribution and contamination assessment of heavy metals in soils from tidal flat, oil exploitation zone and restored wetland in the Yellow River Estuary. Wetlands. doi:10.1007/s13157-015-0637-3

You K, Ma C, Gao H, Li F, Zhang M, Qiu Y, Wang B (2007) Research on the jellyfish (Rhopilema esculentum kishinouye) and associated aquaculture techniques in China: current status. Aquaculture International 15:479-488

Zedler JB (2003) Wetlands at your service: reducing impacts of agriculture at the watershed scale. Frontiers in Ecology and the Environment 1:65-72

Zhang H, Sun T, Shao D, Yang W (2016b) Fuzzy logic method for evaluating habitat suitability in an estuary affected by land reclamation. Wetlands. doi:10.1007/s13157-014-0606-2
Zhang Y, Cui B, Xie T, Wang Q, Yan J. (2016a) Gradient distribution patterns of rhizosphere bacteria associated with the coastal reclamation. Wetlands, in press

Zhang R, Tang J, Li J, Zheng Q, Liu D, Chen Y, et al. (2013) Antibiotics in the offshore waters of the Bohai Sea and the Yellow Sea in China: occurrence, distribution and ecological risks. Environmental Pollution 174:71-77

Zhao Q, Bai J, Liu Q, Lu Q, Gao Z, Wang J (2016) Spatial and seasonal variations of soil carbon and nitrogen content and stock in a tidal salt marsh with Tamarix chinensis China. Wetlands. doi:10.1007/ s13157-015-0647-1

Zhu MS, Sun T, Shao DD (2016) Impact of land reclamation on the evolution of shoreline change and nearshore vegetation distribution in Yangtze river estuary. Wetlands. doi:10.1007/s13157-014-0610-6 